\section{Seasonal Variation in Coverage of Selected Grasses and Forbs in Relation to Grazing Intensities in India}

HARSHWARDHAN R. SANT 1

Lecturer, Department of Botany, Banaras Hindu University, Varanasi-5, India.

Grazing modifies the structure of many plant communities. Fundamentally the grasslands of India are biotic in origin and hence their response to grazing presents many management problems. There are various controversies regarding the ori-

1The author is highly grateful to $D r$. R. Misra, F.N.I., for his valuable guidance and encouragement during the course of this investigation. Thanks are also to the Government of India for the award of a Research Scholarship. gin of these grasslands. Many ecologists consider them to be aseral in stage and biotically controlled. The importance of grasslands in India from the range management and grazing points of view is very high as they are the chief source of fodder for cattle in this area. The pressure for fodder is sufficiently high that various practices are adapted to feed the livestock. They include grazing, scraping and trampling. The influence of grazing, however, is not always well understood.
Various workers have made it clear that individual plants are rarely spread at random within a grassland community (Blackman, 1935 and Clapham, 1936). Ray (1959) while making a phytosociological analysis in northeastern Oklahoma concluded that the aerial coverage used in making the analysis gave the best relationship between various species. The phytosociological differences in the same or different grazing-ground vegetation are important in ecological studies.

The object of this experiment was to study the variations in coverage of the plant species under the influence of grazing on the grassland. The vegetation was charted on meter quadrats to know the actual position of the plants upon the field during the summer and the rainy seasons. Although this method was 
laborious, it gave quantitative results, and when used extensively, furnished a complete picture of the structure of the vegetation above the ground. Charts were taken on protected, medium grazed, and overgrazed fields during the summer and rainy seasons on the grazing grounds of Varanasi, India.

From each chart the area of each species was noted and averaged for each grazing treatment (Table 1).

\section{Discussion}

It is concluded that the plant species occurring in both seasons show increases or decreases in coverage during the rainy season as compared with the summer season. These plants may be grouped as follows:

(1) Plant coverage increases in the rainy season in each type of grazing ground. The reason for such increase during this season is higher availability of moisture which plays an important role in the growth of the plants. They are: Alysicarpus monilifier, Convolvulus pluricaulis, Indigofera linifolia, Desmodium triflorum, Boerhaavia diffusa and Evolvulus nummularius.

(2) Plant coverage decreases during the rainy season in each type of grazing grounds. The main reason for decrease in the coverage of each plant species during this season in spite of higher availability of moisture is higher inter-and intraspecific competition. The plants are Bothriochloa pertusa, Dichanthium annulatum, Evolvulus alsinoides, Vernonia cenera and $\mathrm{Cy}$ nodon dactylon.

There are certain plant species which occur only during one season or the other. Their coverage is recorded in the respective seasons for the different grazing grounds. These are Trichodesma indicia, Blumea lacera, and Volutarella divaricata, occurring in the summer and Dactyloctenium aegyptium, Eragrostis gangetica
Crotalaria medicagenia and Digitaria sanguinalis, etc., occurring during rainy season.

The effect of grazing and other disturbances on the coverage of the grassland species also can be taken into consideration. The plants are grouped according to the intensity of grazing under the following heads:

(1) The coverage increases in response to moderate grazing but further grazing decreases the coverage. These are: Desmodium triflorum, Boerhaavia diffusa, Dichanthium annualtum, Evolvulus alsinoides, Digitaria sanguinalis, Paspalidium flavidium, Eragrostis tenella, Setaria glauca, Sporobolus diander.

(2) The coverage increases as the grazing intensity continues to increase. The species are:

Table 1. Average area occupied by each species during summer and rainy seasons in three fields.

\begin{tabular}{|c|c|c|c|c|c|c|}
\hline \multirow[t]{2}{*}{ Plant species } & \multicolumn{2}{|c|}{ Protected } & \multicolumn{2}{|c|}{$\begin{array}{l}\text { Medium } \\
\text { grazed }\end{array}$} & \multicolumn{2}{|c|}{ Overgrazed } \\
\hline & $\mathbf{S}^{1}$ & $\mathbf{R}^{2}$ & $\mathbf{S}$ & $\mathbf{R}$ & $\mathbf{S}$ & $\mathbf{R}$ \\
\hline & \multicolumn{6}{|c|}{----- square $\mathrm{cm}----$} \\
\hline Alysicarpus longifolius & - & 0.97 & - & 1.24 & - & 1.24 \\
\hline Alysicarpus monilifer & 1.14 & 1.41 & 1.04 & 2.76 & 2.04 & 2.16 \\
\hline Blumea lacera & 0.90 & - & 1.44 & - & - & - \\
\hline Bonnaya brachyata & - & 1.73 & - & 2.38 & - & 0.72 \\
\hline Boerhaavia diffusa & 1.44 & 1.80 & 12.60 & 12.80 & 1.86 & 5.66 \\
\hline Bothriochloa pertusa & - & 2.69 & - & 4.61 & 1.86 & 2.48 \\
\hline Convolvulus pluricaulis & 1.98 & 1.00 & 7.17 & 2.64 & 1.72 & 3.06 \\
\hline Crotalaria medicagenia & - & 4.58 & - & 1.89 & - & 1.87 \\
\hline Cynodon dactylon & 2.10 & 1.11 & 3.81 & 3.17 & 6.20 & 3.01 \\
\hline Dactyloctenium aegyptium & - & 3.52 & - & 2.63 & - & 2.54 \\
\hline Desmodium triflorum & 1.55 & 2.51 & 1.58 & 2.91 & 1.52 & 2.04 \\
\hline Dichanthium annulatum & 3.06 & 1.79 & 6.13 & 3.57 & 2.18 & 1.17 \\
\hline Digitaria sanguinalis & - & 1.08 & - & 3.78 & - & 1.80 \\
\hline Eragrostis elongata & 一 & 1.20 & 一 & 1.21 & 一 & 1.68 \\
\hline Eragrostis gangetica & 一 & 2.09 & 一 & 0.75 & - & 0.62 \\
\hline Eragrostis tenella & 一 & 1.10 & 一 & 1.30 & 一 & 1.00 \\
\hline Aragrostis viscosa & 一 & - & - & 1.08 & 一 & 0.95 \\
\hline Euphorbia hirta & - & 一 & 3.08 & 0.77 & - & 1.82 \\
\hline Euphorbia thymifolia & - & 3.96 & - & 1.76 & 2.20 & 一 \\
\hline Evolvulus alsinoides & 1.82 & 1.04 & 2.90 & 2.72 & 2.10 & 1.50 \\
\hline Evolvulus nummularius & 0.68 & 3.22 & 2.11 & 4.50 & 2.28 & 2.42 \\
\hline Heliotropium strigosum & 一 & - & 1.52 & 1.50 & 1.74 & 3.12 \\
\hline Indigofera linifolia & 1.60 & 4.17 & 3.16 & 3.34 & 1.50 & 3.13 \\
\hline Paspalidium flavidium & - & 0.98 & - & 3.29 & - & 1.60 \\
\hline Panicum psilopodium & 一 & 2.34 & - & 2.11 & - & $\mathbf{2 . 5 5}$ \\
\hline Setaria glauca & - & 0.96 & - & 1.18 & - & 0.40 \\
\hline Sporobolus diander & - & 0.71 & - & 0.90 & - & 0.58 \\
\hline Trichodesma indica & - & - & 3.52 & 一 & 1.52 & 一 \\
\hline Vernonia cenera & 8.91 & 2.47 & 1.68 & 1.98 & 0.98 & 1.40 \\
\hline Volutarella divaricata & - & 一 & - & 一 & 2.64 & - \\
\hline
\end{tabular}

Evolvulus nummularius, Cynodon dactylon, Alysicarpus longifolium, Eragrostis elongata, Euphorbia hirta, and Heliotropium strigosum.

(3) The coverage decreases as the grazing increases. These are: Alysicarpus monilifer, Convolvulus, pluricaulis, Indigofera linifolia, Vernonia cenera, Dactyloctenium aegyptium, Eragrostis gangetica, Crotalaria medicagenia and Euphorbia thymifolia:

(4) Lastly there is Panicum psilopodium. Grazing and protection have no major effect on its coverage.

Thus the effects of grazing and season on the plant coverage are varied. The nature, extent, and frequency of damage caused to the coverage of the plant appear to set up a sequence of metabolic 
events wherein the plant as- yet within the same season it desumes vegetative and reproduc- creases according to the intensity tive growth accordingly. Although the general cover of the herbage is proportional to the moisture supply-being the maximum in the rainy season- of grazing.

\section{LITERATURE CITED}

Blackman, G. E. 1935. A study of statistical methods of the distribution of specics in grassland associations. Bot. Rev. 49: 749-777.
Clapham, A. R. 1936. Overdispersion in grassland communities and the use of statistical methods in plant ecology. Jour. Ecol, 24: 232-251.

RAY, R. J. 1959. A phytosociological analysis of the tall-grass prairie in northeastern Oklahoma. Ecology 40 : $255-261$. 